\title{
Automatic Building of a Semantic Model of Disease Symptoms Based on Text Corpus
}

\author{
G. SZOSTEK, M. JASZUK, A. WALCZAK \\ grazyna.szostek@gmail.com
}

\author{
Faculty of Cybernetics, Military University of Technology, Warsaw \\ University of Information Technology and Management in Rzeszów, Poland
}

\begin{abstract}
The research described in the article refers to the study of data from the domain of medicine. The diagnostic test results are recorded in different ways. They may take the form of tables, graphs or images. Regardless of the original data format, it is possible to draw up their verbal description, which focuses on the description of the observed symptoms. Such descriptions make up the text corpora concerning individual diagnostic technologies. Knowledge on disease entities is stored in a similar manner. It has the form of text corpora, which contain descriptions of symptoms specific to individual diseases. By using natural language processing tools semantic models can be automatically extracted from the texts to describe particular diagnostic technologies and diseases. One of the obstacles is the fact that medical knowledge can be written in a natural language in many ways. The application of the semantic format allows the elimination of record ambiguities. Ultimately, we get a unified model of medical knowledge, both from the results of diagnostic technologies describing the state of the patient and knowledge of disease entities. This gives the possibility of merging data from different sources (heterogeneous data) to a homogeneous form. The article presents a method of generating a semantic model of medical knowledge, using lexical analysis of text corpora.
\end{abstract}

Keywords: semantic network, ontology, natural language processing.

\section{Introduction}

Rapid growth in the amount of information and the inefficiency of the methods for their processing have given rise to work on methods based on formal knowledge representation ontology and the semantic networks. Due to the large number of concepts and relationships between them, the automatic construction of a semantic model [2], [10] is often used. The primary resource used by such methods is the text corpus. Methods of natural language processing [5], [1], [3], [4] developed for text corpora in English cannot be directly translated into the inflected language with free-word order in a sentence, such as Polish. Work on the construction of a semantic network for the Polish language [6], [9] contributed to the development of automated methods for detection of lexical semantic relations.

In many fields (e.g., military, economic, medical) the data do not have a single form: table, picture, graph, etc. Each of them requires the use of dedicated processing and analysis. Since a few years semantic networks are used as a tool for homogeneous recording of heterogeneous data [8]. This approach reveals new possibilities for data processing - the usage of the same methods of analysis of images, texts, tables, etc. The formatting of recorded data allows to decrease their size (e.g., image data), which affects the speed of data transmission over the network.

Medical data are a good example of the diversity of data recording. Building a semantic model described in the article is part of a wider research aimed at creating a data fusion from different resources (heterogeneous data) to a homogeneous form. A given symptom can have a variety of forms (the phrase in the text, a table element, a part of an image, a point on a graph), which is a problem for the further processing of such information. Therefore there is a need to record the symptoms in a single form, which gives the possibility to use the same methods and mathematical tools to assist in the process of diagnosing. The basis for building a semantic model of symptoms are descriptions of results of diagnostic technologies (DT) and descriptions of diseases that make up the text corpus. The paper will present the method of generating a semantic model based on the text corpus. This technique will be used to build an ontology of individual diagnostic technologies and the of disease entities (DE), in order to create structure the diagnostic knowledge.

The structure of the article is as follows. The diversity of medical data collection 
and a proposal of a homogeneous form of their writing is shown in Section 2. The next section, Section 3, provides a brief introduction to the formal ontology and semantic network model. Afterwards, in Section 4 the process of phrase detection denoting symptoms and characteristics specifying them is discussed in detail. Section 5 summarizes the results obtained in Section 4. A general description of the process of building an ontology is presented in Section 6 .

\section{Heterogeneous Data Representation}

The description of the patient's health status and the description of a disease entity consists of descriptions of symptoms detected using different technologies. Below is a set of example diagnostic technologies used in disease diagnostics:

- Physical examination

- $\quad$ Patient questioning

- Skin tests

- Arterial blood gas

- X-ray imaging

- Scintigraphy

- Ultrasonography

- $\quad$ Spirometry

- Bronchoscopy

- Laboratory testing, etc.

Depending on the particular DT, the results vary in form. They can be stored in table form (spirometry, complete blood count), in a graph (spirometry), an image (X-ray), a verbal description (physical examination), etc. Imaging DT often have an additional form of result a short description made by a specialist. Along with graphs the most important parameters of the chart can be provided (in the form of a table). In summary, the DT results, because of the form of recording, can be divided into three forms: table, verbal description, digital image file or analogue images.

As part of a given DT several measurements/observations of parameters of a patient are recorded. The existence of disease symptoms can be ascertained, but also many additional facts about the patient can be recorded. Examples include: affiliation to a profession (e.g. farmer, miner), habits (e.g. smoking), the existence of certain diseases in the patient's family (inherited diseases), age, etc. This information will be recorded and processed by our system in an identical manner as the symptoms. Thus, there was a need for grouping all types of information to assist in diagnosing a disease. This will be done by introducing a separate semantic class, which subclasses will be representing information of interest to us. We called this class a medical attribute (MA). Figure 1 shows an example of a hierarchy of classes derived from the medical attribute class.

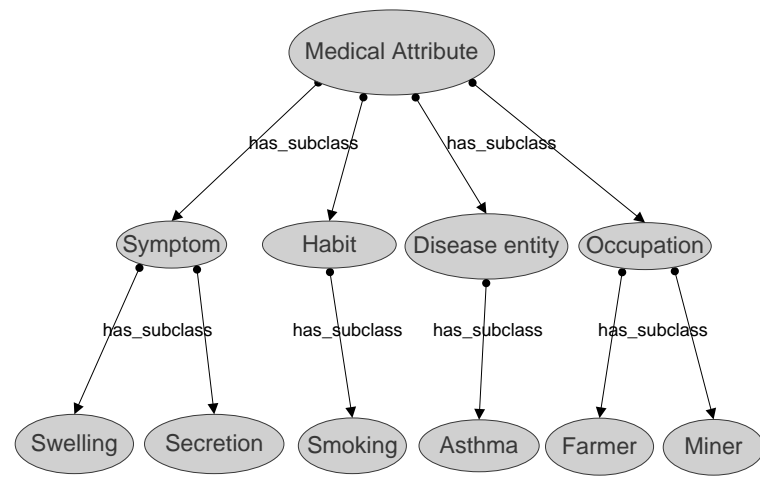

Fig. 1. An example of a hierarchy of classes derived from the medical attribute superior class

MA can be linked to a number of additional parameters that are features that characterize the given attribute. The features include:

- adjective characterizing an attribute (e.g., wydzielina (eng. discharge): gesta (eng. dense), zalegająca (eng. residing), obfita (eng. abundant), etc.);

- $\quad$ place of occurrence (e.g., obrzęk (eng. swelling): błony śluzowej nosa (eng. nasal mucosa), powiek (eng. of eyelids), błony śluzowej gardta (eng. throat mucous membrane));

- time of occurrence or intensification (e.g., kaszel występujący okresowo lub codziennie, w nocy, między 4-5 rano (eng. cough that occurs periodically or every day, at night, between 4-5 am));

- $\quad$ substance evoking a symptom (e.g., sierść zwierzat (eng. animal fur), kurz (eng. dust), pytki roślin (eng. pollen), antygeny (eng. antigens));

- situation, in which there is a symptom (e.g., stres (eng. stress), zmęczenie (eng. fatigue), wysilek fizyczny (eng. physical exercise)).

For each of these features, you can create a separate semantic class, which will be a subclass of the general class named Feature, Figure 2. 


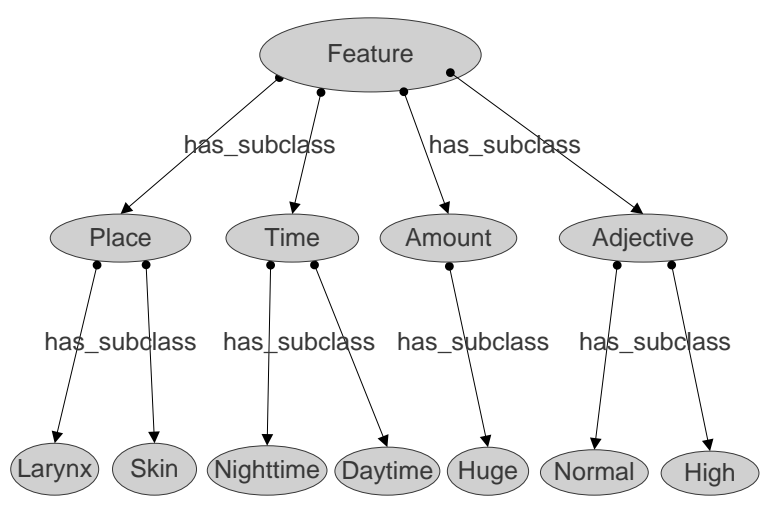

Fig. 2. Hierarchy branch representing the features characterizing the medical attribute

The structure of the hierarchy created in the system therefore has two main branches: medical attributes and features. All other classes are subclasses of either one of these two.

Features and medical attributes will be linked by horizontal relations. The general characteristics of MA represents a fragment of the ontology, in which the central node is a specific attribute. This node will be linked to respective feature nodes characterizing the attribute. The relations between the nodes will depend on the particular type of the MA and the feature (Figure 3). Both the MA and their features are identified in the text using natural language processing methods.

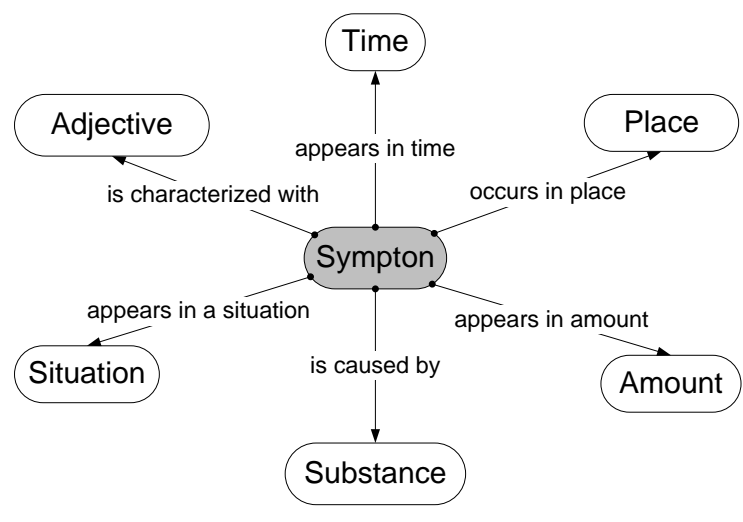

Fig. 3. Exemplary links between symptoms and features that characterize it

\section{Formal Ontology and Semantic Network Model}

\section{Ontology}

Ontology is a hierarchically and orderly structured set of terms used to describe the given field:

$$
O=\langle C, R, L\rangle
$$

$C$ is the set of all concepts used in the built model. Element $R$ of ontology $O$ is the set of relations between concepts:

$$
R=\{\mathfrak{R}: \mathfrak{R} \subset C \times C\} .
$$

The set of relations are further divided into sets of structural relations and hierarchical relations.

The set $L$ is called a lexicon and it is defined as follows:

$$
L=L_{C} \cup L_{R},
$$

where:

$L_{C}-$ set of words, which are the names of concepts, hereinafter called lexicon of terms;

$L_{R}$ - set of words, which are the names of the relations, hereinafter called the relation lexicon.

\section{Semantic Network}

The established ontology definition results in the following formal definition of the semantic network:

$$
S N^{O}=\left\langle I_{C}^{O}, I_{R}^{O}\right\rangle,
$$

where:

$I_{C}^{O}-$ set of instances of all concepts defined in ontology $O$;

$I_{R}^{O}-$ set of instances of all relations between concepts defined in ontology $O$.

If Inst $t_{c}$ is a set of instances of a concept $c$, then

$$
I_{C}^{O}=\bigcup_{c \in C} \text { Inst }_{c} .
$$

The set $I_{R}^{O}$ can be written as follows:

$$
I_{R}^{O}=\bigcup_{\mathfrak{R} \in R} \text { Inst }_{\Re} .
$$

The set Inst $_{\mathfrak{R}}$ is called a set of the instances of the $\mathfrak{R}$ relation.

\section{Process of Creating a Semantic Description of Symptoms}

Descriptions of diagnostic results are written in a natural language. Hence the method of determining phrases describing the symptoms and their features is based on natural language processing techniques. Figure 4 is presents in detail the process of building the semantic symptom description from a single sentence. The result is a single branch of the semantic network, which is a model that describes the symptom or symptoms of a disease. Based on the semantic network, an ontology denoted as $O_{\mathrm{O}}$ will be built. 


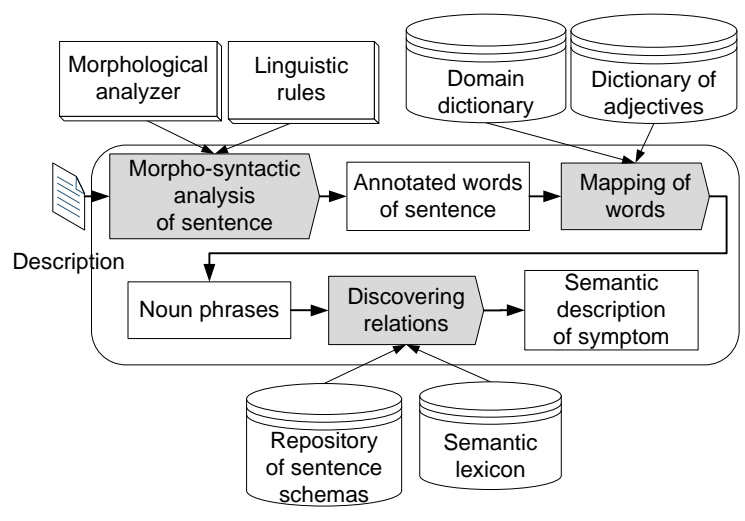

Fig. 4. The process of creating a semantic description of a symptom

Before starting the process of creating a semantic description it is necessary to create the appropriate dictionaries (domain dictionary, dictionary of adjectives, semantic lexicon) and lexical resources (sentence patterns).

\section{Domain Dictionary and Dictionary of Adjectives}

Domain dictionary includes nouns and noun phrases specific for the considered area of knowledge, in this case - of medicine. The dictionary is built using the medical texts corpus (DT results descriptions, DE descriptions, medical literature, etc.) and general text corpora. Adjectives dictionary contains adjectives characteristic for the given field. Assuming the previously defined symbols, the domain dictionary and the adjectives dictionary make up the lexicon $L_{C_{M}}$ of the medicine ontology $O_{\mathrm{M}}$.

\section{Dictionary of Synonyms}

Many of the gathered words in the domain dictionary and in the adjectives dictionary have similar meaning. This means that there is a synonymic relation between them. After identifying such words or phrases, synsets are created, i.e. sets of phrases with the same or similar meaning. The created synsets define semantic classes which are ontology nodes. Each synset represents a certain concept. The concept (the name of the synset) should be the phrase with the highest frequency of occurrence.

The dictionary of synonyms is the set of concepts $C_{\mathrm{M}}$ of the ontology $O_{\mathrm{M}}$. In the hierarchy of semantic classes presented in Figs. 1 and 2 the nodes from the lowest level contain concepts from the dictionary of synonyms.

\section{Semantic Lexicon}

The semantic lexicon associates concepts defined in the dictionary of synonyms $\left(c \in C_{M}\right)$ through a combination of a hierarchical relations with respective classes from the higher ontology levels. As stated in Section 2 there are the following classes representing the groups of concepts: [symptom], [disease entity], [time], [occupation], etc. These classes create higher levels of the hierarchy of classes (Figures 1 and 2).

\section{Morpho-Syntactic Analysis of Sentences}

During the process of creating the semantic descriptions, the descriptions for only one DT or DE are taken into account. Each description consists of a set of sentences. Detection of a symptom and all its features takes place within the context of a single sentence. The process of morpho-syntactic analysis of a sentences is done using a morphological analyzer and linguistic rules. The result of the process are annotated sentences - each word has a morpho-syntactic tag assigned to it.

The process of the analysis consists of the following stages (Figure 5):

\section{- Tokenization}

The sentence is subject to tokenization, which is division into tokens: words, numbers, punctuation marks.

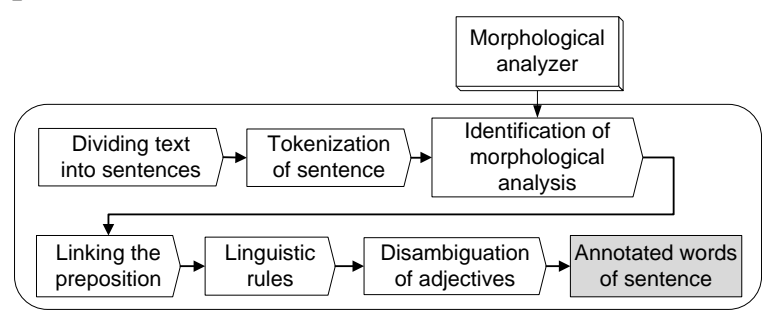

Fig. 5. Process of the morpho-syntactic analysis of a sentence

- Identification of morphological analysis

For each word a sequence inflective analyses is generated by the morphological analyzer. All possible analyses are generated.

- Linking the preposition

The relation of the preposition with the noun is expressed with the aid of the noun endings characteristic for the case permissible in this link. This information allows for a partial disambiguation of some nouns, pronouns, adjectives and numerals occurring in tandem with a preposition.

- $\quad$ Linguistic rule noun + noun in genitive

In this part of the process words interpreted as nouns are analyzed. The goal is disambiguation of the case. The study shows that when there are two nouns next to each other in a sentence, e.g. błona śluzowa oskrzeli (eng. bronchial mucosa), światło oskrzela (eng. bronchial internal 
diameter), świą skóry (eng. itch of skin), etc., then the second word is usually in the genitive case. This property will be used for this noun during the stage of elimination of the grammatical analyses that contain the case other than the genitive.

- Disambiguation of adjectives

The dependence between a noun and an adjective defining it is the formal expression in the form of grammatical endings specific for the common case for both words and for the common number. This feature allows for searching of pairs of a noun and the corresponding adjective in terms of case and the number.

Additionally during the whole process of the morpho-syntactic analysis we are collecting knowledge about the subject and predicate or subjects and predicates in case of complex sentences. A description of this process does not belong, however, to the scope of the article.

During the morpho-syntactic analysis instances of the following relations can be detected:

is_characterized_with,place_of_occurence $\in$ $R_{\mathrm{OS}}$,

where $R_{\mathrm{OS}}$ - a set of relations between the concepts of ontology $O_{\mathrm{OS}}$.

An instance of a relation occurs between two instances of concepts. Not all of the analyzed words of the sentences are instances of concepts $C_{\mathrm{OS}}$ of the defined ontology $O_{\mathrm{OS}}$. Some of them are not covered in the domain dictionary, other part are components of noun phrases. Before the words irrelevant from the symptoms description perspective are eliminated, and before the noun phrases are detected, let us assume that the words in sentences are instances of concepts from a set $C_{\mathrm{x}}$ from some ontology $O_{\mathrm{x}}$.

We can infer occurrence of any specific semantic relation between words only on the basis of morpho-syntactic tags assigned to the words, because at this stage of analysis we do not have any semantic information. Only the morpho-syntactic information is available.

For the relation is_characterized_with the arguments are the words from the found nounadjective phrases:

$$
\begin{aligned}
& \text { Inst }_{\text {is characteried with }}=\left\{(i, j) \in I_{C_{x}}^{O_{x}} \times I_{C_{x}}^{O_{x}}:\right. \\
& a(i) \supset\{\text { noun }\}, \\
& a(j) \supset\{\text { adjective }\}\},
\end{aligned}
$$

where $a: I_{C_{O S}}^{O_{O S}} \rightarrow A, \quad A-$ set of morpho-syntactic tags. The relation between words from noun-noun in genitive exists, but at this stage it cannot be determined what kind of relation it is and what is its direction. The instance of the $\mathfrak{R}$ relationship will be written afterwards as:

$$
\text { instance_relation }(i, j) \text {, }
$$

where: instance_relation $\in$ Inst $_{\mathfrak{R}}, i, j \in I_{C_{O S}}^{O_{o s}}$. If the relation argument is unknown, then '?' is written. When a relation exists, but its type is unknown, then '?relation' is written. Lack of information about the direction of the relation, i.e. what is its left and right argument, it is written accordingly '?left_arg', '?right_arg.' Affiliation to a semantic class is written as a hierarchical type relation has_instance:

$$
\text { has_instance(semantic_class, } i \text { ), }
$$

where: semantic_class $\in C_{\mathrm{OS}}, \quad i \in I_{C_{O S}}^{O_{O S}}$. Adjectives are assigned a semantic class [adjective].

Morpho-syntactic relations between words identified in the analysis can be represented by a graph. Instances of concepts will placed in the nodes, the arrows will represent instances of the relations. Nouns will be placed in the rectangular nodes, while adjectives will be in the oval nodes. Discovered semantic relations will be represented with arrows. Relations, which have to be found will be represented by dashed arrows.

Example 1. Let us analyse a sample sentence Oskrzela pluc sq prawidtowe $z$ nasilonym odczynem zapalnym szczególnie po stronie lewej. (eng. Bronchi are correct with severe inflammatory reaction especially on the left side). The graphs obtained for the above sentence are presented in Figure 6.

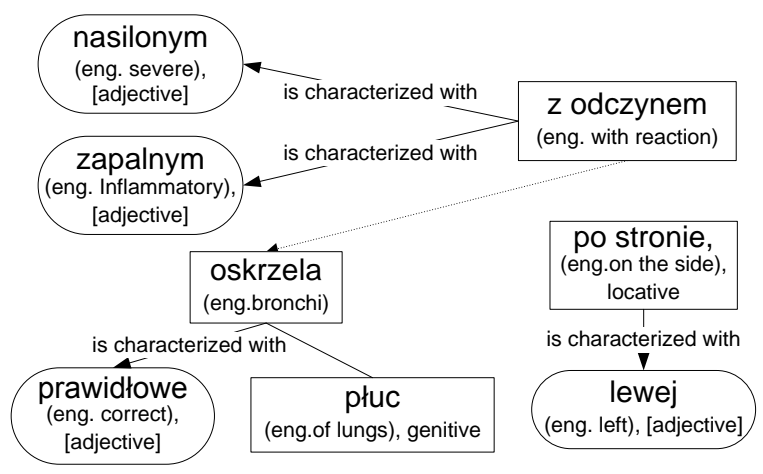

Fig. 6. Morpho-syntactic links between words in the sentence from Example 1

\section{Mapping Words}

The annotation process of single words was described in the previous chapter. Some words, when located directly next to each other, form compounds possessing a new meaning as 
a whole. This meaning is not resultant of the meanings of the components. Thus moving to the semantic level requires detecting noun phrases. As the name suggests, a noun is the central element of phrase. The process of mapping words into phrases is done in several steps using the domain dictionary. For each noun in a sentence:

$$
\forall i \in I_{C_{M}}^{O_{M}}: a(i) \supset\{\text { noun }\}
$$

The following steps are carried out:

1. Creation of the noun phrases where the phrase contains one or more words, on the basis of morphological annotation:

- firstly, for the noun $i$ we are searching related words, not only directly, but also indirectly. Let set $Z_{i}$ contain words linked to the noun $i$ :

$$
\begin{aligned}
& Z_{i}=i \cup\left\{j: j \in I_{C_{M}}^{O_{M}} \wedge i \neq j \wedge\right. \\
& \exists_{r_{k} \in B \subset I_{R_{O S} O S}^{O O S}, k 1, \ldots, n, n \leq|B|} \\
& \left.\left(r(i, j) \vee r_{1}(i, \cdot), \ldots, r_{k}(\cdot, j)\right)\right\},
\end{aligned}
$$

where: $B$ - set of rules from the analysed sentence;

- on the basis of the set of words $Z_{\mathrm{i}}$ a set of $K$ candidate phrases are generated. The word $i$ occurs in each phrase, hence the creation of all the subsets of $\mathrm{Z}_{\mathrm{i}} /\{i\}$ and the resulting phrase is added to the word $i$. For example, if the noun $i$ occurs in relation with other words, as shown in Fig. 6, then the following phrasecandidates will be created for it: $i, i a, i b$, $i c, i a b, i a c, i b c, i a b c$;

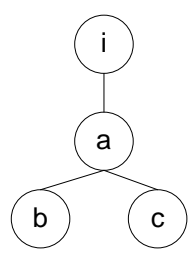

Fig. 7. Exemplary relations of noun $i$ with other words

- not all elements of set $\mathrm{K}$ can be phrases. We need to reject such phrase-candidates, in which elements are unreachable from the node containing noun $i$. For example, the phrases $i b, i c$ from the previous point are rejected.

2. Elimination noun phrases from set $\mathrm{K}$ that do not exist in the domain dictionary. After carrying out this step set $\mathrm{K}$ contains only instances of ontology concepts $-O_{\mathrm{OS}}$ :

$$
K \subset I_{C_{O S}}^{O_{O S}} \subseteq I_{C_{M}}^{O_{M}} .
$$

3. The longest matching phrase $k$ is selected from set $K$.

4. On the foundation of the $k$ phrase, appropriate rules are modified in the database $B$, in order to link the words of the $k$ phrase into one node.

\section{Discovering Relations}

The description of the symptom is composed of many elements semantically related. As previously indicated, these elements are not only adjectives characterizing it, but also elements that describe the location of the occurring symptom, time of occurrence, symptom triggering factors, etc. In the preceding analysis process morpho-syntactic relations were detected existing between words of sentences. The relations form a set of graphs. At this stage of analysis it is required that the semantic relations are detected between the graphs representing the elements of symptom description. The process will run with the use of sentence patterns and semantic vocabulary.

\section{Sentence Patterns}

It could be thought that there are as many sentences as there are combinations of words, which is very large. As it turns out, this is not true. The existence of certain rules and conditions during creation of word combinations causes that they can be expressed in the form of patterns [7]. The verb is the key element of every such pattern. Its semantic and grammatical properties, to a large extent, determine the structure of sentences, in which it occurs. During the process of creating a verbal expression the choice of words and their form depend on other expressions, with which they are associated grammatically and semantically. This entails that sentence patterns can be a very useful tool in solving such semantic problems as determining semantic relations, missing elements in a sentence or meaning of words.

Different parts of a sentence (subject, object, adverbials, etc.) may occupy only the elements belonging to certain lexico-semantic classes. The mandatory and optional linkage must also be distinguished. Mandatory linkage applies to components that need to be associated to a given verb. Optional linkage relates to components, which may, but do not have to be used with the verb. Semantic characteristics of components is used only to determine limitations of linkability. 


\section{Algorithm of Fitting a Sentence to a Sentence Pattern}

The algorithm aims to find a pattern for a given sentence, generate expectations with respect to the missing components and determine the meaning of ambiguous words (in the semantic sense).

Every word passes through the morphosyntactic analysis. Particular attention is paid to the verbs and nouns (noun phrases). Verbs allow for reaching the fitting patterns, and nouns help in selecting one of them.

The first stage consists of assigning instances to respective semantic classes. The semantic dictionary is used for this purpose. For nouns from the noun-noun in genitive pairs the following is checked: if the noun in genitive has the class [anatomy_element], then both nouns are bound with the relation named place_of_occurence and the noun in genitive is written as the second argument of the relation.

After determining the verb in the sentence, the patterns are selected, in which the given verb exists. Then a pre-selection of a pattern is made using the list of noun phrases.

The second step is to resolve ambiguity. If the first phase ended in selecting one pattern from the list and all its components are present in the sentence, then the algorithm ends. The lack of certain phrases in the sentence required by the pattern does not mean that we have chosen the wrong pattern. This kind of a situation can occur when the required noun has already been mentioned in the preceding sentences, or will be discussed in the next sentences. In order to determine what noun it is, in the first case it is necessary to perform a semantic analysis of previous results, and in the second case it is necessary to generate the expected results.

The set of verbs that may occur in descriptions of DE and DT is limited. For most of them the number of sentence patterns is limited to one or two.

Some verbs can appear in many sentence patterns, such as the verb to be. Determining the case for nouns can be an insufficient criterion for the selection of an appropriate pattern. In this case, it is helpful to use the semantic dictionary.

Linking morpho-syntactic information with semantic information will allow for disambiguation of the selection of the sentence pattern, and this will solve the problem of semantic ambiguity.

\section{Example 2}

In the following sentencje: „Oskrzela płuc są prawidłowe $\mathrm{z}$ nasilonym odczynem zapalnym szczególnie po stronie lewej". (eng. Bronchi are normal with increased inflammatory reaction especially on the left side) the verb to be occurs as a predicate. Listed below are a few selected sentence patterns for the to be verb:

1. $\quad \mathbf{N P}-\mathbf{N P}_{\mathbf{N}}+\left(\mathbf{N P}_{\mathbf{M j}}\right)$
$\mathrm{NP} \rightarrow$ [anatomy elem

$\mathrm{NP} \rightarrow$ [anatomy_element]

$\mathrm{NP}_{\mathrm{N}} \rightarrow$ [symptom]

$\mathrm{NP}_{\mathrm{Mj}} \rightarrow$ [property][anatomy_element]

$\mathrm{R}$ : place_of_occurrence $\left(\mathrm{NP}_{\mathrm{N}}, \mathrm{NP}\right)$

is_characterized_with $\left(\mathrm{NP}, \mathrm{NP}_{\mathrm{Mj}}\right)$

2. $\mathbf{N P}-\mathbf{N P}_{\mathbf{N}}+\mathbf{N} \mathbf{P}_{\mathbf{D}}$

$\mathrm{NP} \rightarrow$ [anatomy_element]

$\mathrm{NP}_{\mathrm{N}} \rightarrow$ "location"

$\mathrm{NP}_{\mathrm{D}} \rightarrow$ [symptom]

$\mathrm{R}$ : place_of_occurrence $\left(\mathrm{NP}_{\mathrm{D}}, \mathrm{NP}\right)$

3. $\mathbf{N P}$ - Adj

$\mathrm{NP} \rightarrow$ [symptom]

Adj $\rightarrow$ [property]

$\mathrm{R}$ : is_characterized_with (NP, Adj)

4. $\mathbf{N P}-\mathbf{N P}_{\mathbf{N}}$

$\mathrm{NP} \rightarrow$ [symptom]

$\mathrm{NP}_{\mathrm{N}} \rightarrow$ "symptom"

Explanation of the symbols:

NP: noun phrase;

$\mathrm{NP}_{\mathrm{D}, \mathrm{B}, \mathrm{C}, \mathrm{N}, \mathrm{Mj}}$ : letters at the bottom of noun phrases indicate their grammatical casel (genitive $[\mathrm{D}]$, accusative $[\mathrm{B}]$, dative $[\mathrm{C}]$, instrumental $[\mathrm{N}]$, locative $[\mathrm{M}]$ );

Adj: adjective;

- position of the verb in the sentence pattern;

$+\quad$ between the components means that they are linked without implication of the current sentence pattern;

( ) optionality of components or group of components (i.e. the possibility of omission);

$\rightarrow$ arrow points to the semantic characterization;

[] semantic classes are given for noun phrases;

$\mathrm{R}$ : relation type.

In the branches of discovered relations (during the morpho-syntactic analysis) we receive the following noun phrases: $z$ odczynem zapalnym (eng. with inflammatory reaction), oskrzela (eng. bronchi), po stronie (eng. on the side). 

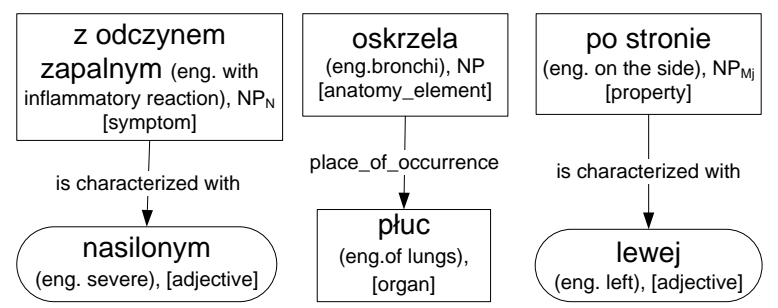

Fig. 8. Relations discovered during the morpho-syntactic analysis

The phrase in the instrumental case occurs in patterns 1 and 4, the phrase in the locative case - (can occur, but not necessarily) only in pattern 1. The subject of the sentence with the semantic class [anatomy_element] appears in pattern 1 and 3. After checking the matching of semantic classes pattern 1 is selected. Graphs are completed with new relations as presented in Figure 8.

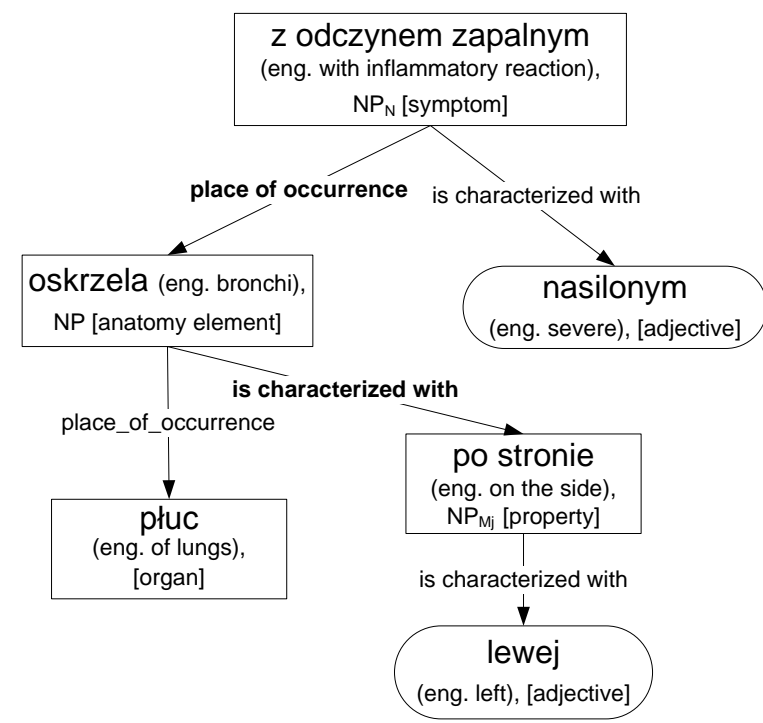

Fig. 9. A graph representing the semantic description of the sentence from example 2

\section{Semantic Network for the Diagnostic}

The product of the process of detecting phrases with the meaning of symptoms and features characterising the symptoms, the semantic network based on the text is created. Each of the sentences provides a single branch of the network structure. The semantic network is the foundation for building the ontology $O_{\mathrm{os}}$. From the previously introduced formal specification of the semantic network, it is known that the network is defined by two sets. For the built ontology $O_{\mathrm{OS}}$ it will be:

$$
S N^{O_{O S}}=\left\langle I_{C_{O S}}^{O_{O S}}, I_{R_{O S}}^{O_{O S}}\right\rangle,
$$

where:

$I_{C_{O S}}^{O_{O S}}-$ set of instances of ontology $O_{\mathrm{OS}}$ classes; the set is comprised of words (phrases) appearing in all descriptions analyzed for a given DT or DE; it should be indicated that $I_{C_{O S}}^{O_{o s}} \subseteq I_{C_{M}}^{O_{M}}$

$I_{R_{O S}}^{O_{O S}}$ - set of instances of the relations between classes $C_{\mathrm{OS}}$ of the $O_{\mathrm{OS}}$ ontology, the set contains all relations discovered during the analysis of texts referring to a DT or DE.

\section{Creating Ontologies of the Medical Knowledge}

Creating ontologies is done by eliminating synonyms from the semantic network extracted from text and associating the nodes and relations into a single model.

A given piece of information can be expressed in many ways using a combination of words or phrases with similar meaning. The elimination of synonyms phase allows for replacing such phrases with the names of concepts from the dictionary of synonyms (Figure 9):

$$
\forall i \in I \subset I_{C_{O S}}^{O_{o S}}, V_{C_{o S}}^{O_{o s}}(i) \in C_{O S},
$$

where: $V_{C_{O S}}^{O_{O S}}: I_{C_{O S}}^{O_{o s}} \rightarrow C_{O S}$;

$I_{C_{O S}}^{O_{O S}}$ - set of instances of concepts $C_{\mathrm{OS}}$ defined in the $O_{\mathrm{os}}$ ontology;

$I$ - set of concept instances in the analyzed sentence.

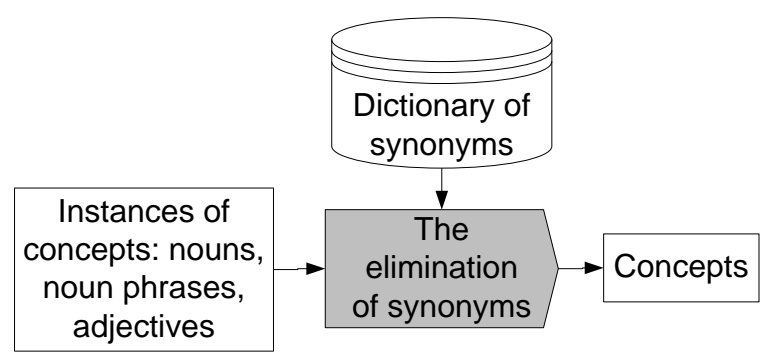

Fig. 10. The scheme of eliminating synonyms

The semantic network reduced to a network of concepts is transformed into an ontology by eliminating multiple repetitions of the same semantic relations.

\section{Conclusion}

Automatic building of a semantic model of disease symptoms based on text corpora is a tool 
for building models of a diagnostic technologies or a disease entities. A DT model created in the described way can be used for acquisition of the patient's diagnostic data. The model is a good foundation for user interface through which it is possible to collect and semantize the symptom descriptions. The DE model is being built in order to standardize the description of disease entities. By using a uniform format for both the DE description and the description of the patient health condition, it is possible to carry out the diagnostics using all possible data.

Further work will be focused on improving results of the morpho-syntactic analysis, by developing a system with the ability of automatic identification of sentence patterns. Developing a method for initial selection of sentences with respect to information that is of interest to us is also desired. This would allow for rejection of sentences that do not contain information relevant from the point of view of the description of symptoms.

\section{Bibliography}

[1] Burgess C., "Representing and resolving semantic ambiguity: A contribution from high-dimensional memory modeling", in Gorfein, D.S. (Ed.), On the Consequences of Meaning Selection: Perspectives on Resolving Lexical Ambiguity, APA Press. (2001).

[2] Chen H., Lynch K.J. , "Automatic construction of networks of concepts characterizing document database", IEEE Transactions on Systems, Man and Cybernetics, Vol. 22, No. 5, 885-902, (1992).

[3] Harris Z.S., "Mathematical Structures of Language", Interscience Publishers, John Wiley \& Sons Inc., New York, 1968.

[4] Hearst M.A., "Automatic Acquisition of Hyponyms from Large Text Corpora", Proceedings of the Fourteenth International Conference on Computational Linguistics, Nantes, (1992).

[5] Lund K., Burgess C., "Producing highdimensional semantic spaces from lexical co-occurence", Behavior Research Methods, Instrumentation, and Computers, 28, 203-208, (1996).

[6] Piasecki M., Derwojedowa M., Koczan P., Przepiórkowski A., Szpakowicz S., Zawisławska M., ,Półautomatyczna konstrukcja Słowosieci”, URL www.plwordnet.pl/main, the web page of the project, (2007) (in Polish).
[7] Polański K. (red.), Stownik syntaktyczno-generatywny czasowników polskich, t. 1-7, Kraków (1980-1993) (in Polish).

[8] Rohmer J., "The Case for Using Semantic Nets as a Convergence Format for Symbolic Information Fusion in NATO", RTO-MP-IST-040 Information Systems Technology Panel (IST) symposium on "Military Data and Information Fusion", Prague, Czech Republic, (2003).

[9] plWordNet, the web page of the project. URL: http://www.plwordnet.pwr.wroc.pl/ main. (2007).

[10] Velardi P., Fabriani P., Missikoff M., "Using text processing techniques to automatically enrich a domain ontology", in: Proceedings of the International Conference on Formal Ontology in Information Systems - Volume 2001, FOIS'01, ACM, New York, NY, 270-284, 2001. 


\section{Automatyczna budowa semantycznego modelu objawów chorobowych na bazie korpusu słownego}

\section{G. SZOSTEK, M. JASZUK, A. WALCZAK}

Opisane w artykule badania dotyczą danych $\mathrm{z}$ dziedziny medycyny. Wyniki badań diagnostycznych rejestrowane są na różne sposoby. Mogą mieć postać tabel, wykresów, obrazów. Niezależnie od oryginalnego formatu danych możliwe jest sporządzenie ich opisu słownego, który koncentruje się na opisie zaobserwowanych objawów chorobowych. Opisy takie tworzą korpusy słowne dotyczące poszczególnych technologii diagnostycznych. W podobny sposób zapisywana jest wiedza dotycząca jednostek chorobowych. Ma ona postać korpusów tekstowych, w których zawarte są opisy objawów specyficznych dla poszczególnych schorzeń. Posługując się narzędziami przetwarzania języka naturalnego, możliwe jest automatyczne wydobycie z tekstów modeli semantycznych opisujących poszczególne technologie diagnostyczne oraz choroby. Pewne utrudnienie stanowi fakt, że wiedza medyczna może zostać zapisana w języku naturalnym na wiele sposobów. Zastosowanie formatu semantycznego pozwala wyeliminować te niejednoznaczności zapisu. W konsekwencji dostajemy ujednolicony model wiedzy medycznej, zarówno od strony wyników technologii diagnostycznych opisujących stan pacjenta, jak i wiedzy dotyczącej jednostek chorobowych. Daje to możliwość dokonania fuzji danych pochodzących z różnych źródeł (danych heterogenicznych) do postaci homogenicznej. Artykuł przedstawia metodę generowania modelu semantycznego wiedzy medycznej wykorzystującą analizy leksykalne korpusów słownych.

Słowa kluczowe: sieć semantyczna, ontologia, przetwarzanie języka naturalnego. 